\title{
Attributes, Environment Factors and Women Entrepreneurial Activity: A Literature Review
}

\author{
Isidore Ekpe Norsiah Mat \& Razli Che Razak \\ College of Business, Universiti Utara Malaysia, 06010 Sintok, Darul Aman, Malaysia \\ E-mail: ekpe60@yahoo.com,norsiah@uum.edu.my,raz1152@uum.edu.my
}

Received: February 23, $2011 \quad$ Accepted: April 6, $2011 \quad$ doi:10.5539/ass.v7n9p124

\begin{abstract}
Purpose: The purpose of this study is to examine the effect of individual attributes and business environment factors on the entrepreneurial activity of women entrepreneurs. Individual attributes such as education, working experience, attitude towards risk-taking, affect women entrepreneurial activity. Economic constraints such as lack of credit due to lack of asset collaterals and socio-cultural barriers, lack of savings due to low household income, and lack of labour skills due to low educational level also affect women entrepreneurial activity. The effect of these factors on entrepreneurial activity is worth studying because entrepreneurship development is considered a vital link to an overall economic growth of a nation through its positive impact on economic development especially at the grassroots. However, limited studies have reviewed literatures on individual attributes and business environment factors on the entrepreneurial activity of women entrepreneurs. This is the focus of this study.
\end{abstract}

Methodology: The paper is a descriptive study that reviews literature on individual attributes and environment factors on women entrepreneurial activity.

Conclusion: The paper concludes that environment factors exert much more influence on women entrepreneurial activity than individual attributes.

Research limitation: The paper is limited to a literature review that may need further research by using a framework to investigate the factors on entrepreneurial activity.

Practical implication: It shows the need for the government to support entrepreneurs through adequate provision of micro-finance.

Originality: The study is a new way to look at crucial factors affecting entrepreneurial activity in a country.

Paper type: This is a research paper.

Keywords: Attributes, Environment factors, Women entrepreneurial activity

\section{Introduction}

The identification and exploitation of entrepreneurial opportunity for business start-up or diversification, and subsequent performance depends on the individual attributes of the entrepreneurs and the business environment. Examples of such business environment are competition and lack of micro-finance factors like credit. Individual attributes play a vital role in enterprise activity because entrepreneurship involves risk, and attitude towards risk differ between individuals (Shane, 2003).

Despite the role of individual attributes in exploiting entrepreneurial opportunity for new business or business diversification by women entrepreneurs; however, recent studies have shown that business environment factors such as economic, financial and socio-cultural, plays a greater role in the exploitation of entrepreneurial opportunities by women entrepreneurs (Kuzilwa, 2005; Shastri \& Sinha, 2010; Vob \& Muller, 2009). For example, Kuzilwa (2005), Shastri \& Sinha, (2010) argued that though all conditions for exploiting entrepreneurial opportunity such as education, experience, and energy may exist, but the environmental constraints such as lack of credit, and societal discriminations especially in developing countries, may hinder the entrepreneur. The study is hinged on the fact that there is scarcity of research that reviews literatures on individual attributes and business environment factors on the entrepreneurial activity of women entrepreneurs (e.g Kuzilwa, 2005; Shane, 2003; Shastri \& Sinha, 2010). 


\section{Literature Review}

The theories most commonly applied in research on entrepreneurship are McClelland's (1961) theory of the need to achieve, and Rotter's (1966) locus of control theory. McClelland's theory suggests that individuals with a strong need to achieve often find their way to entrepreneurship. Rotter's theory suggests that the locus of control of an individual can be seen as either internal or external. The internal control expectation is related to learning and thus motivates and supports active striving, while the external control expectation impedes learning and encourages passivity. An internal control expectation is usually associated with entrepreneurial characteristics (Littunen, 2000). The pull/push model is also a common way of explaining different motives behind why women start a business (Brush, 1999; Buttner \& Moore, 1997). Push factors refer to necessities such as unemployment, glass ceiling, redundancy, recession, financial reasons (inadequate family income), dissatisfaction with being employed, or the need to accommodate work and home roles simultaneously. Pull factors are related to independence and the need to succeed better than others as entrepreneurs. According to Rotter's theory, the locus of control of an individual manifests in the need for achievement, financial reasons (desire for profit-wealth), personal development, self-fulfilment, social status and power (Hansemark, 1998; Glancey et al., 1998). However, the situation is rarely a clear-cut selection of pull or push factors, and the factors are often combined (Brush, 1999).

\subsection{Attributes}

The characteristics or attributes of women entrepreneurs are regarded as the pull factors in entrepreneurial activity (Hisrich, Peters \& Shepherd, 2008; Kuzilwa, 2005; North, 1990). These include demography such as age and education, type of employment, type of industry, type of company, financial background and work experience (Harrison \& Mason, 2007; Peter, 2001; Okpukpara, 2009). They are regarded as the human capital or internal factors to be contributed by the entrepreneur in exploiting entrepreneurial opportunity for business performance. The ones most critical to women entrepreneurs which are discussed below are education, attitude and experience.

Education: Education is one of the characteristics of women entrepreneurs that can affect their business performance, and literature supports that education and managerial experience may contribute to women's business growth but certainly has positive impact on entrepreneurial performance (Gatewood, Brush, Carter, Greene \& Hart, 2004). They also stated that human capital is not only the result of formal education and training but also include experience and practical learning derived from previous paid employment or managerial position, and it is a vital condition for technological innovation (Gatewood et al., 2004). According to Wit and Van (1989), individuals with a high level of education are more likely to engage in entrepreneurship. An individual with more work experience, a higher level of education, more knowledge of the market and business practice is more likely to be able to identify an opportunity for starting a new business. On the other hand, it may be expected that people with a low level of education have more difficulties finding a paid job, and therefore see no other possibility than to engage in entrepreneurship. Hence, high educated people are more likely to pursue opportunity-based ventures, while less educated entrepreneurs are more involved in necessity entrepreneurship (Bhola et al., 2006).

In a related study; education, experience, age and social networks were also found to have significant positive influence on entrepreneur's business performance in USA (Shane, 2003), yet women entrepreneurs in developing countries have low educational levels than their counterparts in developed countries (Ibru, 2009). More specific to women studies done by Kavitha et al. (2008), women were found to be more matured in terms of age, level of education and equipped with work experience in comparison to non-entrepreneurs. In USA for example, most women entrepreneurs had tertiary education followed by high school education (Gatewood et al; 2004); though in France for example, a higher percentage of women entrepreneurs had high school education and were in their early 30s (Carter \& Shaw, 2006).

Attitude: Attitude towards risk-taking is another crucial attribute of entrepreneurs especially women. This is because enterprise involves risk-taking, and risk-averse entrepreneur is less likely to exploit entrepreneurial opportunity (Shane, 2003). Attitude towards risk-taking is entrepreneur's ability and willingness to engage in risky activity (Shane, 2003). Studies have found that attitude and behavioural intention are positively related (Crisp \& Turner, 2007) and that attitude towards behaviour leads to intention which eventually leads to actual behaviour (Ajzen, 1991).

Experience: Literature asserted that business experience is one of the vital entrepreneurial characteristics (Antoncic, 2006), and evidences support the fact that a minimum of two to three years business experience is sufficient to assess an entrepreneur (Antoncic, 2006; Kuzilwa, 2005; Carter \& Shaw, 2006). Other characteristics 
of women entrepreneurs include: strong desire for independence, innovation, risk-taking, resourcefulness, business skills, knowledge, and networks (Salman, 2009). Business knowledge includes knowledge of top players in the industry, knowledge of product range and market trends. Business skills include technical and managerial skills which could be acquired through training, seminars and workshops. Experience could be acquired through formal education and business knowledge (Salman, 2009).

The need for achievement and autonomy, risk-taking, control of business and self-efficacy are other vital characteristics of women entrepreneurs (Shane, 2003). Demography, skills and reputation are also essential attributes of women entrepreneurs as single women had less income and less guarantees for loan. Family size also affects women entrepreneurial activity. Despite the fact that women with one or two children were likely to participate in entrepreneurial activity, in Pakistan for example, in order to generate income to support their families (Salman, 2009), it was however discovered that most women with family sizes of more than five people were likely to become entrepreneurs (Allen, Elam, Langowitz \& Dean, 2008; Lawal, Omonona, Ajani \& Oni, 2009); and large family size is common in developing countries (Lakwo, 2007). Again, most women aged between 25-34 years were found in the early- stage entrepreneurship (Allen et al., 2008). Innovation and decision-making ability are other characteristics (Cunha, 2007). Ambition, self-confidence and high level of energy have also been recognized as vital entrepreneurial characteristics (Idris \& Mahmood, 2003). Having the right motive of venturing into business has been found to be one of the attributes of women entrepreneurs. The right motive should be the first determinant before entering into business (Mitchell, 2004; Porter \& Nagarajan, 2005; Shane, 2003). Self-evaluation and intuition are also crucial characteristics (Shane, 2003). However, focusing on education, experience and attitude towards risk-taking as vital individual attributes of women entrepreneurs, we therefore make the following proposition:

P1: Attributes of women entrepreneurs (education, experience, attitude towards risk-taking) affect women entrepreneurial activity.

\subsection{Environment factors}

Women entrepreneurs face peculiar challenges in an attempt to achieve success (Hatcher, Terjersen \& Planck, 2007) and women in less developed countries face much more barriers to formal economic participation than those in developed countries (Allen et al; 2008). Women face unique obstacles in starting and growing their firms such as lack of skill or training, limited access to capital or credit, lack of savings and social networks, and limited choice of industry (Akanji, 2006; Ibru, 2009; Lakwo, 2007; Martin, 1999; Ojo, 2009; Peter, 2001).

Gender-related discriminations, especially in developing countries, occasioned by socio-cultural factors also pose hindrance to women entrepreneurial activity (Otero, 1999). Such discriminations are in the area of distribution of social wealth such as education and health (May, 2007; Mayoux, 1999; Otero, 1999; Porter \& Nagarajan, 2005; Roomi \& Parrot, 2008).

The type of industry and the industrial differences also affect entrepreneurial performance, and people in knowledge industry have high propensity to access information which leads to business performance in terms of market size and growth (Shane, 2003). Incidence of informal sector investment was higher among firms in the manufacturing, wholesale and retail, and knowledge industry in UK and Canada respectively (Carter \& Shaw, 2006; Riding, 2006). Women entrepreneurs are mostly found in agriculture, services such as education and health, retail and manufacturing where they had experience or where experience was not necessary (Akanji, 2006; IFC, 2007; Okpukpara, 2009). Such businesses are most active in the urban centres, except agriculture (Carter \& Shaw, 2006). The concentration of women entrepreneurs in these sectors is due to their low level of education because higher educational attainment leads to the possibility of self-employment in economically rewarding industry (Stohmeyer, 2007).

The business environment factors pose a lot of challenges to business because they are outside the control of the business owner. Such environmental constraints which are sometimes volatile include the economic, financial, legal, political and socio-cultural factors. These factors play a greater role in entrepreneurial activity because, despite the possession of the requisite personal entrepreneurial characteristics such as education, right attitude to risk, motivation, energy and working experience; the environment may hinder women entrepreneurs from exploiting entrepreneurial opportunities (Kuzilwa, 2005; Shastri \& Sinha, 2010; Vob \& Muller, 2009).

Business environment factors that seem to be more important to the success of women entrepreneurial activity is financial aid or credit accessibility. Credit or loan is very necessary for new and growing enterprises. Banks, not surprisingly, are inclined toward low-risk ventures. Women were more likely to observe that they were not given due respect by financial institutions; they did not think their account managers were easy to talk to; they reported that they were not made to feel comfortable by financial institutions; and they perceived that bank employees 
discriminated against women. Bankers' pessimistic view of women's credit worthiness fostered a reluctance to grant credits. This constituted another obstacle to female entrepreneurship.

On the positive side, however, the popularity of the micro-credit strategy propelled a global movement toward making micro-loans available to people all over the world. Advocacy groups, existing banks, NGOs, and alliances such as the International Coalition on Women and Credit, RESULTS Education Fund (USA), Women's World Bank, Grameen Bank (Bangladesh), Accion International (USA), FINCA (USA), SEWA (India), VOICE (Africa) and many others promoted the idea of micro-credit micro-enterprises in policy circles. In Georgia, women made up $30 \%$ of the borrowers at the Micro-finance Bank of Georgia with an average loan size of $\$ 7,000$. In Ukraine, women obtained $38 \%$ of EBRD Small Business Fund loans and women represented 35\% of the entrepreneurs purchasing newly privatized land parcels. In Malawi, a micro-finance regulatory framework and strategy were launched in 1998. In Bangladesh, Grameen Bank reported a loan repayment rate of 95-98\% from women entrepreneurs (Accion International, 1997; Counts, 1996; Estes, 1999; Shawa, 1999).

The importance of access to credit is identified as a major barrier to entry into self-employment throughout the world. Women setting up micro-enterprises, SMEs, or formal large-scale businesses all encountered varying degrees of difficulty in obtaining capital, collateral, and fair lending terms. In fact, according to a study by Clark and Kays (1995), $41 \%$ of entrepreneurs reported that lack of money is the greatest obstacle to starting a business, and $47 \%$ cited lack of capital as the greatest barrier to business growth.

Riding (2006) stated that higher percentage of enterprises especially in Canada mostly seek external finance than use personal savings. Much dependence on credit by entrepreneurs, especially women, is due to their inability to raise capital through personal savings (Brana, 2008). The problem is much pronounced in developing countries due to unemployment and gender discrimination in high-paid jobs (Brana, 2008; Carter \& Shaw, 2006). However, Gatewood et al. (2004) contended that women use more of personal savings than credit, to start and grow their enterprises.

A relationship also exist between credit and opportunity for entrepreneurial activities of women entrepreneurs. Credit provides the needed opportunity for entrepreneurs to start or improve business in order to make profit and improve their lives (Allen et al., 2008; Brana, 2008; Lans et al., 2008; Majumdar, 2008; Roslan \& Mohd, 2009; Salman, 2009; Shane, 2003; Tata \& Prasad, 2008). There is a positive relationship between credit and opportunity for entrepreneurial activity. For example, credit was found to have positive effect on opportunity for entrepreneurial activity of women in USA (Allen, 2000), Nigeria (Akanji, 2006) and France (Brana, 2008).

Salman (2009) also argued that loan is not usually good for business start-up but for growing or existing enterprises due to inability of the new business to pay back the loan at the initial business stage. While Karnani (2007) contended that credit does not lead to women's improved welfare rather the government should create jobs for the women. These arguments aside, numerous evidences abound in the literature that credit has positive impact on enterprise performance. For instance, previous studies found that credit had positive impact on enterprise profit in Nigeria, Nicaragua, Canada and Croatia (e.g. Martin, 1999; Ojo, 2009). However, focusing on credit as a vital micro-finance factor, we therefore make the following proposition:

\section{P2: Credit affects women entrepreneurial activity.}

In order to examine the composite effect of individual attributes and business environment factors on women entrepreneurial activity, we therefore make the following proposition:

P3: Attributes of women entrepreneurs (education, experience, attitude towards risk-taking) and credit affect women entrepreneurial activity.

\section{Conclusion}

Individual attributes such as education, experience and attitude toward risk-taking are vital to entrepreneurial activity of women entrepreneurs. Business environment factors, for example credit is also important for entrepreneurial activity. However, literatures have lent strong support to the fact that business environment factors such as credit accessibility exert much more influence on the entrepreneurial activity of women entrepreneurs than individual attributes. This is so because an entrepreneur may have the requisite characteristics for exploiting entrepreneurial opportunity but the environmental constraints may constitute a great hindrance.

\section{Acknowledgement}

We like to thank the members of the proceeding and publications committee (among whom is Dr. Yuslizawati Mohd Yusoff), the editorial board, the organizers and participants of the $2^{\text {nd }}$ International Accounting and 
Business Conference 2011, University Teknologi MARA, Malaysia for reviewing this paper and making useful comments especially during the presentation.

\section{References}

Ajzen, I. (1991). The Theory of Planned Behaviour. The Organizational Behaviour and Human Decision Processes, 50, 179-211. doi:10.1016/0749-5978(91)90020-T, http://dx.doi.org/10.1016/0749-5978(91)90020-T

Akanji, O. O. (2006). Microfinance as a strategy for poverty reduction. Central Bank of Nigeria Economic and Financial Review, 39 (4).

Allen, D. W. (2000). Social networks and self-employment. Journal of Socio-Economics, 29 (1), 487-501. doi:10.1016/S1053-5357(00)00086-X, http://dx.doi.org/10.1016/S1053-5357(00)00086-X

Allen, I. E., Elam, A., Langowitz, N. \& Dean, M. (2008). 2007 Global Entrepreneurship Monitor report on women and entrepreneurship. Babson College: The Centre for Women's Leadership.

Antoncic, B. (2006). Impacts of diversification and corporate entrepreneurship strategy making on growth and profitability: A normative model. Journal of Enterprising Culture, 14 (1), 49-63. doi:10.1142/S0218495806000040, http://dx.doi.org/10.1142/S0218495806000040

Brana, S. (2008). Microcredit in France: Does gender matter? 5th Annual Conference-Nice. European Microfinance Network.

Carter, S. \& Shaw, E. (2006). Women's business ownership: Recent research and policy developments. UK: Small Business Service.

Clark, P., \& Kays, A. (1995). Enabling entrepreneurship: Microenterprise development in the United States. Washington, DC: The Aspen Institute.

Counts, A. (1996). Give us credit. New York: Times Books.

Crisp, R. J., \& Turner, R. N. (2007). Essential Social Psychology. London: SAGE Publication.

Cunha, M. P. (2007). Entrepreneurship as decision-making: Rational, intuitive and improvisational approaches. Journal of Enterprising Culture, 15 (1), 1-20. doi:10.1142/S0218495807000022, http://dx.doi.org/10.1142/S0218495807000022

Estes, V. (1999, November 18). Women \& business development: promoting economic growth and job creation. USAID/Europe \& Eurasia Bureau: author.

Gatewood, E. J., Brush, C. G., Carter, N. M., Greene, P. G. \& Hart, M. M. (2004). Women entrepreneurs, growth and implications for the classroom. USA: Coleman Foundation whitepaper series for the USA Association for Small Business and Entrepreneurship.

Harrison, R. T. \& Mason, C. M. (2007). Does gender matter? Women business angels and the supply of entrepreneurial finance. Entrepreneurship Theory and Practice, 31 (3), 445-472. doi:10.1111/j.1540-6520.2007.00182.x, http://dx.doi.org/10.1111/j.1540-6520.2007.00182.x

Hatcher, C., Terjesen, S. \& Planck, M. (2007). Towards a new theory of entrepreneurship in culture and gender: A grounded study of Thailand's most successful female entrepreneurs. Australia: AGSE.

Hisrich, R. D., Peters, M. P. \& Shepherd, D. A. (2008). Entrepreneurship (7th ed.). New York: McGraw-Hill Co. Inc.

Ibru, C. (2009). Growing microfinance through new technologies. Federal University of Technology, Akure, Nigeria.

Idris, A. M. M. \& Mahmood, R. (2003). Bank managers' perceptions of the characteristics of successful entrepreneurs. Malaysian Management Review. [Online] Available: http://www.google.com (August 25, 2009)

International Finance Corporation (IFC). (2007). Gender entrepreneurship markets, GEM country brief. Afghanistan: GEM.

Karnani, A. (2007). Microfinance misses its mark. Stanford Social Innovation Review. [Online] Available: http://www.ssireview.org/articles (February 18, 2009) 
Kavitha, R., Anantharaman, R.N. \& Sharmila, J. (2008). Motivational factors affecting entrepreneurial decision: A comparison between Malaysian Women Entrepreneurs and Women Non-entrepreneurs. Communications of the IBIMA, 2, 85-89.

Kuzilwa, J. (2005). The role of credit for small business success: A study of the National Entrepreneurship Development Fund in Tanzania. The Journal of Entrepreneurship, 14 (2), 131-161. doi:10.1177/097135570501400204, http://dx.doi.org/10.1177/097135570501400204

Lakwo, A. (2007). Microfinance, rural livelihood, and women's empowerment in Uganda. African Studies Centre Research Report 85/2006. [Online] Available: http://www.ascleiden.nl/pdf/rr85lakwo.pdf (August 3, 2009)

Lans, T., Hulsink, W., Baert, H. \& Mulder, M. (2008). Entrepreneurship education and training in a small business context: Insights from the competence-based approach. Journal of Enterprising Culture, 16 (4), 363-383. doi:10.1142/S0218495808000193, http://dx.doi.org/10.1142/S0218495808000193

Lawal, J. O., Omonona, B. T., Ajani, O. I. Y., \& Oni, O. A. (2009). Effects of social capital on credit access among cocoa farming households in Osun State, Nigeria. Agricultural Journal, 4 (4), 184-191.

Majumdar, S. (2008). Modelling growth strategy in small entrepreneurial business organizations. The Journal of $\begin{array}{lllll}\text { Entrepreneurship, } & 17 & \text { (2), } & 157-168 . & \text { doi:10.1177/097135570801700204, }\end{array}$ http://dx.doi.org/10.1177/097135570801700204

Martin, T. G. (1999). Socio-economic impact of microenterprise credit in the informal sector of Managua, Nicaragua. [Online] Available: http://scholar.lib.vt.edu/thesis/ (January 21, 2009)

May, N. (2007). Gender responsive entrepreneurial economy of Nigeria: Enabling women in a disabling environment. Journal of International Women's Studies, 9 (1).

Mayoux, L. (1999). From access to empowerment: Gender issues in microfinance. Women's Caucus Position Paper for CSD-8; 2000. CGAP.

Mitchell, B. C. (2004). Motives of entrepreneurs: A case study of South Africa. Journal of Entrepreneurship, 13 (1), 168-183.

North, D. C. (1990). Institutions, institutional change and economic performance. Cambridge, UK: Cambridge University Press.

Ojo, O. (2009). Impact of microfinance on entrepreneurial development: The case of Nigeria. Faculty of Administration and Business, University of Bucharest, Romania.

Okpukpara, B. (2009). Microfinance paper wrap-up: Strategies for effective loan delivery to small scale enterprises in rural Nigeria. Journal of Development and Agricultural Economics, 1 (2), 41-48.

Otero, M. (1999). Bringing development back into microfinance. Latin America: ACCION International.

Peter, B. K. (2001). Impact of credit on women-operated microenterprises in UASIN GISHU district, Eldoret, Kenya. In P. O. Alila \& P. O. Pedersen (eds). (2001). Negotiating social space: East African microenterprises. ILO, Geneva, database. [Online] Available: http://books.google.com.my/book? (September 18, 2009)

Porter, E. G. \& Nagarajan, K. V. (2005). Successful women entrepreneurs as pioneers: Results from a study conducted in Karaikudi, Tamil Nadu, India. Journal of Small Business and Entrepreneurship, 18 (1), 39-52.

Riding, A. (2006). Small Business financing profiles. Canada: SME Financing Data Initiative.

Roomi, M. A. \& Parrot, G. (2008). Barriers to development and progression of women entrepreneurs in Pakistan. The Journal of Entrepreneurship, 17 (1), 59-72. doi:10.1177/097135570701700105, http://dx.doi.org/10.1177/097135570701700105

Roslan. A. H. \& Mohd, Z. A. K. (2009). Determinants of microcredit repayment in Malaysia: The case of Agrobank. Humanity and Social Sciences Journal, 4 (1), 45-52.

Salman, A. (2009). How to start a business: A guide for women. Pakistan: Centre for International Private Enterprise, Institute of National Endowment for Democracy, affiliate of the USA Chamber of Commerce.

Shane, S. (2003). A general theory of entrepreneurship: The individual-opportunity nexus. UK: Edward Elgar.

Shastri, R. K. \& Sinha, A. (2010). The socio-cultural and economic effect on the development of women entrepreneurs (with special reference to India). Asian Journal of Business Management, 2 (2), 30-34. 
Shawa, M. (1999). A forum and study on policy options for promoting the economic empowerment of women: The case of Malawi. Lilongwe, Malawi: United Nations Economic Commission for Africa and Malawi's Ministry of Women, Youth, and Community Services

Stohmeyer, R. (2007). Gender gap and segregation in self-employment: On the role of field of study and apprenticeship training. Germany: German Council for Social and Economic Data (RatSWD).

Tata, J. \& Prasad, S. (2008). Social capital, collaborative exchange and microenterprise performance: The role of gender. International Journal of Entrepreneurship and Small Business, 5 (3/4), 373-385. doi:10.1504/IJESB.2008.017310, http://dx.doi.org/10.1504/IJESB.2008.017310

Vob, R. \& Muller, C. (2009). How are the conditions for high-tech start-ups in Germany. International Journal of Entrepreneurship and Small Business, 7 (3), 285-311.

Wit, G. \& Van Winden,F. (1989). An empirical analysis of self-employment in the Netherlands. Small Business Economics, 1 (4), 263-272. doi:10.1007/BF00393805, http://dx.doi.org/10.1007/BF00393805 